\title{
The Pacific mission press
}

The missions were the first to bring printing presses to the region and usually the first to establish a newspaper in the various islands. Despite their limited circulations, churchnewsppers are still important because of their role in preserving local languages and because of their historical function.

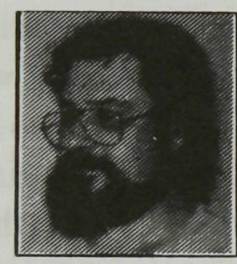

\section{By PHILIP CASS}

TO HAVE an effective newspaper you must have a means of production and a common written language which both writer and reader understand. The early missionaries brought both to the Pacific. They introduced the first printing presses and were the first to learn the local languages and put them down in writing. They published hymn books, Bible extracts and sermons in the newly learnt languages and taught the local people to read and write their own tongue. Of course, the version of the language that was written down was not always accurate, since it was heard through European ears and it sometimes took decades to develop a really accurate written version of a language.

The missionaries worked in the local languages because they had to live and work among the people. It was no use preaching at them in English or French or German. They sometimes had anthropological reasons for their work, believing that they were preserving the languages and customs of people who would, they thought, soon be swept away by the inexorable advance of Western civilisation. But when they came to codify those languages their motives were practical and intimately connected with their mission.

Which version of the language was to be saved was another question altogether. It was not unknown for two different missions to use different orthographies to record a single tongue; as for instance the Methodist renderiung of Kuanua words with a ' $q$ ' and the Catholic method of using a ' $g$ '. Mastering a language was fine if there was one dominant language with only a few regional dialects. (The Bau dialect dominates as the written version of Fijian simply because the Methodists decided that it be so.) But what about a place like Papua New Guinea, where there are nearly 1000 languages? A missionary could 


\section{PHILIP CASS}

master one language and find that it was utterly incomprehensible to the people in the next village.

The religious reasons for the missionaries' printing activities should be readily apparent, but there were other reasons. Fistly there was intense rivalry between the missions. the Protestants and Catholics were, of course, antagonistic, but there was also rivalry between the rival Protestant churches. The Methodist and London Missionary Society missionaries, for instance, quarrelled over which denomination was to evangelise Samoa. ${ }^{1}$ Thus, the mission newspapers were often used to attack other denominations and rally the faithful. ${ }^{2}$ The English language church papers attacked each other and one can expect that similar antagonisms were carried out in the local language press. What must they have thought of these Europeans who preached love and forgiveness and vilified each other so openly?

The missions also became involved in secular affairs. In most instances they were among the first foreigners to settle permanently in the Pacific and by the time the islands were claimed as colonies and colonial government arrived, they had established often quite powerful positions. The Finnish historian Arne Koskinen's thesis on the role of the missionaries in the Pacific as active agents of colonialism is quite valid, although French gunboats were of more use to the Marists in Polynesia than the Sacred Heart Missionaries in New Guinea. ${ }^{3}$ How far the political involvement of the missions int he colonial/political sphere process was transmitted though the mission press cannot be deduced without undertaking a massive program of translation and comparison with contemporaneous government documents.

The churches could mediate between the islanders and the colonial rulers and especially help to hinder the working of recruiting vessels looking for labourers to work in Queensland or Samoa. Perhaps unwittingly, the work of the missionaries in introducing literacy to the islands, helped to empower the local people in their dealings with the colonial authorities. There is, for instance, a famous case involving a Tolai big man who had his mission-educated son write out a list of men who were overdue on a labour contract and then presented it to the German administrator. ${ }^{4}$

In the beginning, books and other material intended for readers in the islands had to be printed in England, France, Germany, America or Australia, but this could lead to trouble. The first book intended for a Pacific audience,Te Aebiu No Tahiti, was published in London in 1810. It was riddled with spelling mistakes because the printer in London could not read Tahitian and had no idea when he was making a mistake, a disaster for what was meant to be a spelling book. The missionaries in the field were really the only ones qualified to print in the island languages. Some missionaries arrived in the islands with printing 
presses, while others waited years for the machinery. To some, a printing press was a vital tool of evangelisation, while to others it was a luxury that could be indulged in once the mission field was settled.

The establishment of a printing press also enhanced the reputation of the mission. The first Protestant evangelical missions were often staffed by people who would never have risen above their allotted station in life if they had not been missionaries. One early London Missionary Society party was described as being

very much lower middle class and the laymen were for the most part tradesmen... [of] limited educated and puritanical leanings. ${ }^{5}$

Thus, any work they did, and intellectual work in particular, raised their prestige with their co-religionists at home and raised their social status. The first printing press in the Pacific was established in Tahiti in 1816 by London Missionary Society and run by William Ellis. The king watched the missionaries typesetting the first publication printed in the islands. ${ }^{6}$ The next was established in Hawai'i in 1821 by Hiram Bingham of the American Board of Commissioners for Foreign Missions. Methodist missionaries brought the first printing press to the Kingdom of Tonga in 1831, their first production being a four-page spelling book. The next mission press was established inthe Cook Islands in 1834.? Because of its effect on Methodist work in German New Guinea, it is worth considering, albeit briefly, the work of the mission presses in Fiji. The first printing press in Fiji was brought into the country by the Methodists and the first book printed at Lakeba in 1839. ${ }^{8}$ Griffin dates the Methodist newspaper $A i$ Tukutuku Vakalotu to 1828 , but it may have been running earlier. ${ }^{9}$

The Marists arrived in Fiji in 1844, but did not print anything in Fijian until 1864 , probably due to the fact that they made little headway in a country where Methodism prevailed. The first book was printed in Sydney. The first Catholic paper, A Talanoa was printed in 1894 , two years after the mission had bought the Suva Times press for $\$ 50$. Until then they had, like most of the pioneers, made do with a hand operated machine. Fr Marion was put in charge of the monthly leaflet, which, apart from disseminating the Christian message, was to oppose the Methodist Ai Tukutuku Vakalotu. A Talanoa changed its name to A Talanoa mi Lotu kei nai tukutuku Eso in 1895. By 1897, 700 copies were printed every month. ${ }^{10}$ Fr Rougier, the missionary at Rewa, had a small press and produced a calendar with much useful information, a combination almanac and list of saints' days, complete with advertising to defray the costs. He was discouraged from doing any more printing after some of his more narrow minded colleagues attacked him for printing a reader containing Fijian myths. 


\section{PHILIP CASS}

In 1839 a press was established in Apia in Samoa. The first production of the Apia press was O Le Tala I Lotu Ese Ese, an anti-Catholic tract that also acted as a rallying point for the warring Protestant factions. ${ }^{11}$ Long before these machines were established, material for both countries had been printed in Tonga, where the missionaries had established a considerable presence. A press was established in the Wallis islands in 1844. In 1848, the LMS and Presbyterian missionaries arrived in the New Hebrides (Vanuatu) with a press. Anglican missionaries established a press int he Loyalty Islands in 1852 and in 1854 , Marist missionaries arrived in New Caledonia with the first lithographic press in the Pacific. The press was not much used and in 1859 was sold to the French colonial government which used it to produce the colony's first newspaper, Moniteur Imperiale de la Nouvelle Caledonie et Dependences. The Foreign Missions of Boston were in the Carolines in 1856, bringing with them a small hand press with which they produced a sheet of prayers and hymns. In 1860 they had expanded their activities to the Marshalls where they printed a 44-page primer. $^{12}$

Hiram Bingham Jnr followed his father's footsteps into the Pacific and in 1857 was in the Gilbert Islands (Kiribati). He learned the local language and had the first book printed at Pohnpei in 1858, sending the others to Honolulu for printing in 1861. However, instead of sending him back a completed book, his fellow missionaries in Hawai' i sent him a printing press and bade him do the job himself. Young Hiram was apparently less than overjoyed at the prospect, but a shipwrecked sailor called Hotchkiss turned up who was willing to become a printer. The Lord indeed moves in mysterious ways. The Marists also established a newspaper on Kiribati called Te Niutipepa. ${ }^{13}$

The Marists established the first press in the Solomons at Rua Sura in 1910. ${ }^{14}$ They began printing a newspaper, $\mathrm{Na}$ Turupatu no Lotu Katolika in January 1911. ${ }^{15}$ The paper was printed in Tangarare (or Gare as it was also called) the language most widely used at the western end of Guadalcanal where the Marists had been successful. As the Lutherans had done with Jabem, Kate and Graged, the Catholics hoped to use Gare as a lotu language throughout the mission. The experiment proved a failure, as had the Divine Word mission's trial with Boikin in the Sepik. ${ }^{16} \mathrm{O}$ ' Reilly describes the following as 'a very rough translation' of the paper's aims as stated in its first issue:

The news here for you Catholics, to teach you the things of the Church to tell you also the work of Catholics in the whole Solomons and the work of Catholics in [other] places... You who know how to read books... Do not read for you alone, go tell our to all...to the Catholics, the old people, the women, the children who stay in the village... ${ }^{17}$ 
Turupatu consisted of six to 10 articles concerning spiritual subjects, news about the Society of Mary, general church news, but more importantly, local news, stories, legends and the everyday events that made up people's lives. ${ }^{18}$

It is not certain whether the Marists established a press in New Guinea until after the First World War. Writing in 1917, Urens says there was a press in the North Solomons, a geographical term that encompases Bougainville and Buka. ${ }^{19}$ However, according to O'Reilly and Laracy it was not until 1926 that machinery was installed at Banoni and the following year at Torikina, well after the establishment of the Australian mandate and 16 years aftrer the missionaries had first arrived there. ${ }^{20}$ Until then material for Buka and Bougainville was either roneoed locally or printed in sydney or in the Solomons proper. The first publication for the Northern Solomons appears to have been Katekismokairikina Lotu Katolika peuna, published in Sydney in 1907 in Alu, a language of the Shortland Islands. O'Reilly and Laracy also list a roneoed publication, Lotu Katolika, Tele-nake kaikai. 1. Uki-Akarau, destined for the Buin people. As far as I have been able to ascertain, the first Marist newspaper on Bougainville or Buka was not produced until 1958 when it published Catholic News in a mixture of English and Tokpisin. ${ }^{21}$

The European expansion into the Pacific culminated in the Australian and German annexation of different parts of eastern New Guinea, West Papua having been claimed by Holland as Dutch New Guinea. (While West Papua is part of the Pacific, it is seen as the southernmost limit of European colonisation in Asia). Missionary presses were established in German New Guinea by the Lutherans at Finshafen, the Divine Word missionaries at Tumleo and later Alexishafen, and by the Methodists and Sacred Heart missionaries in Rabaul. The first missionary newspaper was Jaeng Ngajam, published in Jabem by the Lutherans in 1905, followed by the Methodists' Kuanua A Nilai Ra Davot in $1909 .{ }^{22}$

Althought he importance of the missionary press as a pioneering enterprise cannot be overstated, it cannot be denied that it was eventually overshadowed by the establishment of the commercial press in the islands. No newspaper can exist with the means of production or a common wrtten language of communication, but a commercial press also needs a commercial environment that can guarantee its continued existence. It did not matter if the missionary press lost money - although as O'Reilly notes, Fr Rougier seems to have had an eye to the economics of printing.

Only when there was a large enough expatriate population could a commercial press develop. The relationship of the indigenous population to the commercial press varied according to the colonial power's language policy. Whereas most missions had worked solely inthe local language, colonial 


\section{PHILIP CASS}

governments were usually more concerned to have the local people taught in the colonial tongue. This made communication easier and also helped to unite linguistically separated people.

Given that the colonial press was almost exclusively aimed at the expatriate market, there would have been very little reason for local people to buy The Fiji Times or The South Pacific Post. It is impossible, however, to make general statements about the situation in the Pacific. In some countries the government early on produced newspapers of news sheets in the local language (as with $\mathrm{Na}$ Mata in Fiji) or in the various forms of pidgin that predominate in Melanesia. ${ }^{23}$

What can be said is that in only one country do the missions exert an influence on the commercial press and that is a direct result of a pragmatic change of direction in language policy. Word Publishing in Papua New Guinea is jointly owned by the SVD missionaries, inpartnership with the Lutheran, Anglican and United churches. The company produces The Independent, an upmarket English weekly; PNG Business, a monthly, Weekend Sport and Wantok, a national Tokpisin weekly. Wantok was first published in 1970. The paper succeeded against all odds - and with the help of massive donations from outside funding agencies - to become a highly respected publication occupying a unique market.

Wantok would not have existed if there had not been a market of Tokpisin readers and they in turn would not have existed without the development of Tokpisin as a lingua franca in PNG. The Divine Word missionaries were uniquely placed to exploit this market because they had opted to use Tokpisin as a lotu language in 1928. They had been unable to find a single language that was understandable on the north coast of New Guinea and, after Australia captured German New Guinea, had been forbidden to teach German in their schools. Instead, they chose Tokpisin and were able to greatly expand their activities. They produced PNG's first Tokpisin newspaper, a parish bulletin called Frend Bilong $\mathrm{Mi}$, in $1927 .{ }^{24}$

The other missions found themselves trapped to a certain extent by their own language policies, their purity of purpose in adapting one local language having led them into an evangelical cul de sac. Wantok would not have been possible if the SVDs had not abandoned any idea of working in one language. Papua New Guinea is a unique case and it should not be thought that the success of Wantok means that the early mission efforts elsewhere were a complete waste of time.

Today there are still many church publications in the Pacific, printed in a variety of languages. They still have a very small circulation and most are concerned exclusively with parochial matters. As will be seen from the accompanying list, most publications use the language of one of the metropoli- 
tan powers. This seems ironic, given the commitment of the early missionaries to preserving local languages. However, a closer reading indicates that English is used either alongside an indigenous language, such as Samoan, or alongside one of the lingua franche of Melanesia.

\section{Contemporary church publications:}

Layton lists more than 30 publications with some sort of church or mission connection in her survey of the Pacific press. However, given that so many church publications do not circulate outside their particular parish or circuit her list is incomplete. I have collected a number of parish news sheets in PNG and doubtless many others could be found elsewhere in the Pacific. Layton's list, is important because it shows the commitment by the churches to publishing in the local language, even if it is often used in tandem with the language of the former colonising power. The following list is based on Layton with some of my own additions:

Cook Islands:

Kia Orana Times. Quarterly in English, circulation 300.

Fiji:

Contact. Catholic weekly, in English Fijian and Rotuman, circulation 2000.

PCC News. Pacific Council of Churches, quarterly, circulation 750.

Spotlight. Anglican quarterly in English, circulation 3000.

French Polynesia:

Le Semeur Tahitien. Fortnightly in French, circulation 2000.

$V$ 'a Katorika. Monthly in Tahitian.

Guam:

Pacific Voice/Umatuna Si Yuos. English weekly, circulation 7000.

Kiribati:

Te Itoi ni Kiribati. Ten issues a year, circulation 2000.

New Caledonia:

Eglise en Vouvelle-Caledonie. French monthly.

Papua New Guinea:

A Nilai Ra Davot. Kuanua/Tok Pisin. Relaunched 1993 after several year's absence. It has the oldest pedigree of any newspaper in PNG.

Arena. Liturgical Catechetical Institute quarterly in English. Circulation 1000.

Catholic Commission for Justice, Peace and Development Newsletter. Quarterly in English and Tok Pisin. Circulation 100.

Family. Anglican tri-annual in English. Circulation 500.

Good News. Anglican monthly in English. Circulation 200.

Kaikai Bilong Tudai. CCJPD monthly in English. Circulation 500.

Kristen Media Productions Newsletter. English language quarterly. Circulation 500 Niuginin Luteran. Tok Pisin monthly. Salvation Army Newsletter. English language weekly. Circulation 160.

Sivarai. Motu quarterly. Circulation 2000

Tanget. English language quarterly. Circulation 1000. 


\section{PHILIP CASS}

The Light. English language quarterly. Circulation 1000.

Tok Aut. English/Tok Pisin monthly.

Tultul. Tok Pisin monthly. Circulation 10,000

Umben. Tok Pisin quarterly. Circulation 1000.

\section{Samoa:}

Tautai. Catholic News for Samoans. Fortnightly in English and Samoan.

\section{Solomon Islands:}

Eastern Solomons Nius. SDA monthly in English. Circulation 500.

Provincial Newsletter. Church of Melanesia monthly in English.

Voice Katolika. English and Pijin monthly.

\section{Tonga:}

Taumu'a Lelei. Tongan and English monthly. Circulation 5800.

Tuvalu:

Te Lama. Ekalesia Tuvalu monthly in Tuvaluan. Circulation 250.

\section{Vanuatu:}

Bahai'i News. Monthly in English and Bislama. Circulation 250

Eklesia. Monthly in French, Bislama and English.

\section{Bibliography:}

Calvert, James, Fiji and the Fijians, Vol 2. James Calvert. London, 1858 (reprinted by the Fiji Museum, 1985.)

Cass, P., 'Mission journalism in German New Guinea - Pioneering Mass Communication,' in Melanesian Journal of Theology. VIII:2, October 1992.

- 'New Guinea's First Newspapers: the missionary press in German New Guinea 1886-1914,' in Australian Journalism Review XIII:1-2, January-December 1992.

- 'Mission resurrects PNG newspaper,' in Australian Journalism Review XV:2, July-December, 1993.

Cryle, D., The Press in Colonial Queensland, University of Queensland Press, Brisbane, 1989

Danks, Rev B., In Wild New Britain, Angus and Robertson, Sydney, 1933.

Garret, J., To Live Among the Stars: Christian Origins in Oceania, USP/WACC, Suva/Geneva, 1992.

Gilson M. and Zubrzycki, J., The Foreign Language Press in Australia 1848-1964, ANU, Canberra, 1964.

Griffen, Vanessa, 'Control of the press and information in the British colonies 193955 with a case study of Fiji. Phd thesis. University of Sydney, 1991.

Kent, G., The Company of Heaven, A. H \& W.H.Reed, Auckland, 1972.

Koskinnen, Arne, Missionary Influence as a Political Factor in the Pacific Islands, Finnish Academy of Sciences, Helsinki, 1953.

Laracy, Hugh, Marists and Melanesians: A History of the Catholic Missions in the Solomon Islands, ANU, Canberra, 1976.

Layton, Suzanna. The Contemporary Pacific Islands Press. University of Queensland, 1992. 
Lingenfelter, R., Presses of the Pacific Islands 1817-1867, The Plantin Press, Los Angeles 1967.

Mihalic, F., SVD, Interview, Kairiru Island, 1992.

Nelson, H. 'The Press in Papua New Guine,' Paper presented at history seminar, Port Moresby, 1967.

O'Reilly, Fr P., SM, and Laracy, H. Bibliographie des ouvrages publiee par les Missions Maristes des Isles Salomons, Publications de la Societe des Oceanistes, Paris, 1972.

Streit, R., OMI, and J. Dindinger, OMI, Missionum Bibliotecum, Verlag Herder, Freiburg, 1954.

Threlfall, Neville, One Hundred Years in the Islands. Toksave Buk, Rabaul, 1975. Urens, B., SJ, 'Die Catholische Presse in Ozeanien' in Die Catholischen Missionen: Illustrierte Monatschrift, July, 1917.

Wagner, E. and Reiner, H. (eds), The Lutheran Church in Papua New Guinea, Lutheran Publishing House, Adelaide, 1986.

\section{Notes:}

'Garreth, J., To Live Among the Stars: Christian Origins in Oceania (Suva/Geneva, 1992) p79.

${ }^{2}$ Even a cursory examination of contemporary Catholic and Protestant newspapers such as the Annals of our Lady of the Sacred Heart and the Methodist church papers intended for home consumption will confirm this.

${ }^{3}$ Koskinnen, A., Missionary Influence as a Political Factor in the Pacific Islands (Helsinki, 1953) passim; S. Firth, New Guinea Under the Germans (Port Moresby, 1985) p136. Plans for a French warship to visit the MSCS on Yule Island were abandoned under pressure from Australia. P. O'Reilly, SoM, and H. Laracy, Bibliographie des ouvrages publiee par les Missions Maristes des isles Salomon (Paris, 1972) p18.

${ }^{4}$ Danks, Rev B., In Wild New Britain (Sydney, 1988) p 229.

${ }^{5}$ Kent, G., The Company of Heaven (Auckland, 1972) p 27.

${ }^{6}$ Lingenfelter, R., Presses of the Pacific Islands 1817-1867 (Los Angeles, 1967) pp 3-4, 6 .

${ }^{7}$ Ibid, p 34, 36, 51.

${ }^{8}$ Calvert, J., Fiji and the Fijians. Vol II (London 1859/Suva 1985) p 221.

${ }^{9}$ Griffin, V., 'Colonial Press Control' PhD thesis (University of Sydney, 1991) p147. See also Calvert p 221-231. Calvert goes into great detail about the Methodist press, but does not mention their newspaper.

${ }^{10}$ O'Reilly, P., SoM, Imprints of the Fiji Catholic Mission including the Loreto Press 1864-1954 (Suva, 1959) pp 9-10.

"Lingenfelter, R., Presses of the Pacific Islands..., pp 70-71.

${ }^{12}$ Ibid, pp 47, 76, 88, 94-105.

${ }^{13}$ Streit, R., OMI, and J. Dindinger, OMI, Missionum Bibliothecum (Freiburg, 1954) p 711.

${ }^{14}$ Laracy, H., Marists and Melanesians..., (Canberra, 1976) p95; P.O'Reilly, SoM 


\section{PHILIP CASS}

and H. Laracay, Bibliographie des ouvrages...,p 2.

${ }^{15} \mathrm{O}$ 'Reilly and Laracy, Bibliographie des ouvrages..., p18.

${ }^{16}$ Laracay, H., Marists and Melanesians..., p 95. See also O'Reilly and Laracy, Bibliographie des ouvrages..., p 1. '...le dialecte de Gare, va devenir la langue diffusee par la mission.'

17 Ibid., p18.

${ }^{18} \mathrm{Ibid}$., p19. 'On y trouve egalement des petitets histoires locales, des contes ou des legendes indigines, des conseils de sante...'

19 Urens, B., SJ, 'Die Catholische Presse in Ozeanien' in Die Catholischen Missionen: Illustrierte Monatschriff, July 1917 p 220. 'Freilich beschranten sich einige diser Druckereien, wie die auf den Sud und Nord Salomonen...' Urens apparently believed that the Marists had set up printing presses everywhere they went: 'In alle diesen missionen haben die Maristen in lause dere zeit druckereien eroffnet..'

${ }^{20}$ O'Reilly and Laracy, Bibliographie des ouvrages..., p 47.

${ }^{21}$ Ibid., pp 51, 62.

${ }^{22}$ Wagner, E. and Reiner, H. (eds) The Lutheran Church in Papua New Guinea (Adelaide, 1986) p 447 and Threlfall, N. One Hundred Years in the Island (Rabaul, 1975) p 87.

23. See Griffen, V. Colonial Press Control in Fiji for a full list of colonial newspapers, including government and private publications in Fijian and Hindi. Nelson, H., The Press in Papua New Guinea (Port Moresby, 1967) lists government publications in Tokpisin.

${ }^{24}$ Mihalic, F., SVD, Interview, Kairiru Island, April 1992.

$\square$ Philip Cass was until recently a Lecturer in Journalism at the University of the South Pacific, Fiji, and he is a!so an editorial board member of PJR. 